\title{
SISTEM INFORMASI PENGUKURAN UJI KOMPETENSI KARYAWAN BERBASIS WEBSITE PADA PT SURYA TOTO INDONESIA TbK KABUPATEN TANGERANG
}

\author{
Muhammad Rachman Mulyandi ${ }^{1}$ \\ Rizqi Eka Saputri ${ }^{2}$ \\ Dosen STMIK Raharja ${ }^{1}$,STMIK Raharja Jurusan Sistem Informasi ${ }^{2}$ \\ Jl. Jendral Sudirman No. 40, Modern Cikokol, Tangerang ${ }^{1,2}$ \\ Email: mulyandi@raharja.info ${ }^{l)}$, rizqiekasaputri@raharja.info ${ }^{2)}$
}

\begin{abstract}
ABSTRAK
Uji kompetensi adalah salah satu faktor yang sangat penting pada PT Surya Toto Indonesia, dengan adanya uji kompetensi maka dapat membantu perusahaan untuk mengetahui perkembangan kinerja karyawan. Kebutuhan akan sebuah sistem informasi yang terkomputerisasi menjadi landasan dirancangnya sistem ini. Dilakukan perancangan sistem ini karena pelaksanaan uji kompetensi tertulis yang berjalan saat ini masih berupa kertas dan proses penilaian secara manual, sehingga hasil yang diperoleh dari uji kompetensi tersebut belum efektif dan efisien. Dengan adanya sistem yang baru, dapat memberikan informasi yang lebih efektif dan akurat bagi perusahaan dalam pengukuran uji kompetensi karyawan. Adapun metode penelitian yang digunakan dalam penelitian ini yaitu metodologi observasi, studi pustaka, dan wawancara. Hasil yang didapat dari sistem ini diantaranya HRD tidak lagi memberikan nilai secara manual melainkan oleh sistem, dan mempercepat HRD dalam pembuatan laporan hasil uji kompetensi. Selain itu, sistem ini juga dapat mempermudah karyawan dalam mengetahui langsung hasil nilai kompetensi.
\end{abstract}

Kata kunci : Uji Kompetensi, Sistem Informasi, Metode Observasi.

\begin{abstract}
Competence is one very important factor in PT Surya Toto Indonesia, with its competence then it can help companies to know the development of employee performance. The need for a computerized information system into the runway he designed this system. Redesign this system because of the execution of written competency test runs are currently still in the form of paper and the assessment process manually, so that the results obtained from the competency test is effective and efficient. With the new system, can provide information a more effective and accurate for the company in employee competence measurement. As for the research methods used in this study is a methodology literature study, observation and interviews. The results obtained from this system include HRD no longer provide value manually but by the system, and speed up the HRD in reporting results of competence. In addition, this system can also facilitate employees in a direct result of knowing the values of competency.

Keywords: competence, information systems, methods of observation.
\end{abstract}

\section{PENDAHULUAN}

Perubahan yang terjadi pada bidang Sumber Daya Manusia diikuti oleh perubahan pada kompetensi dan kemampuan dari seseorang yang mengkonsentrasikan diri pada Sumber Daya Manusia. Kompetensi menjadi sangat berguna untuk membantu organisasi. Perkembangan kompetensi yang semakin luas dari praktisi Sumber Daya Manusia memastikan bahwa Manajemen Sumber Daya Manusia memegang peranan penting dalam kesuksesan organisasi.

Sumber Daya Manusia (SDM) merupakan salah satu faktor penting untuk meningkatkan produktivitas kinerja suatu perusahaan, Oleh karena itu diperlukan sumber 
daya manusia yang mempunyai kompetensi tinggi seperti dilihat dari pengetahuan, keterampilan, dan kedisiplinan, karena keahlian atau kompetensi akan dapat mendukung peningkatan prestasi karyawan, yang digunakan untuk mengukur kompetensi karyawan yaitu berupa ada tes psikotes, pengujian observasi, dan pengujian wawancara.

PT Surya Toto Indonesia Tbk perusahaan yang bergerak di bidang manufaktur barang dengan jenis sanitary wares, kitchen set dan plumbing fitting. Dalam pergerakannya di bidang manufaktur, CV Surya menjalin kerjasama dengan TOTO Ltd dari Jepang. CV Surya kemudian berubah nama menjadi PT Surya Toto Indonesia Tbk. PT Surya Toto Indonesia adalah perusahaan yang memiliki jumlah sumber daya manusia yang lumayan banyak yaitu kurang lebih berjumlah 2.800 karyawan, berdasarkan data terakhir yaitu bulan April 2016 dan kemungkinan karyawan dapat bertambah dan berkurang pada bulan-bulan berikutnya (sumber : PT Surya Toto Indonesia, per April 2016). Dengan jumlah karyawan yang banyak dibutuhkan tenaga terampil dan tenaga ahli, dalam hal ini peran sumber daya manusia sangat penting karena terkait dengan proses pengukuran uji kompetensi kayawan.

Dalam sistem pengukuran uji kompetensi karyawan pada perusahaan ini belum dilakukan secara optimal, karena pada sistem pengukuran uji kompetensi karyawan terdapat faktor-faktor uji kompetensi yang belum berbasis komputerisasi, akan menyebabkan lembar jawaban dinilai satu persatu. Jika demikian maka akan memungkinkan terjadi kesalahan dalam penilaian.

Dengan adanya sistem komputerisasi yang lebih akurat diharapkan dapat membantu pihak terkait dalam penyusunan dan perekapan laporan data uji kompetensi karyawan. Pihak terkait tersebut adalah bagian HRD perusahaan yang bisa langsung memberikan hasil dari uji kompetensi yang diikuti oleh karyawan dan bagi karyawan pun akan bisa dengan segera mengetahui hasil dari uji komptensinya sehingga bisa mengetahui kinerja dan kepuasannya agar lebih termotivasi lagi dalam bekerja. Dengan demikian dukungan sistem komputerisasi sangatlah menunjang untuk pelaksanaan uji kompetensi.

\section{PERMASALAHAN}

Peneliti menemukan beberapa masalah yang dihadapi dalam menjalankan sistem yang sedang berjalan seperti :

1. Pada sistem pembuatan laporan rekap nilai kompetensi karyawan belum optimal dikarenakan faktor-faktor berikut:

a. Banyaknya lembar jawaban yang harus dikoreksi, membutuhkan proses waktu yang lama.

b. Uji kompetensi yang belum berbasis komputerisasi, akan menyebabkan lembar jawaban dinilai satu persatu. Jika demikian maka akan memungkinkan terjadi kesalahan dalam penilaian.

2. Pada uji kompetensi tes tertulis masih berupa kertas sehingga menyebabkan pemborosan kertas dan menumpuknya lembar jawaban. Dan karyawan harus menunggu hasil nilai uji kompetensi kurang lebih selama 1 minggu setelah waktu ujian dilangsungkan.

\section{PEMECAHAN MASALAH}

Setelah mengamati dan meneliti dari beberapa permasalahan yang terjadi pada sistem yang berjalan, maka penulis mengusulkan beberapa alternatif pemecahan dari permasalahan yang dihadapi, antara lain: 
1. Dengan merancang dan membangun sebuah sistem yang terkomputerisasi untuk uji kompetensi karyawan, yang merupakan sebuah model sistem baru dan modern, dimana HRD tidak harus mengoreksi satu persatu, dengan demikian akan mempermudah dalam penilaian kedalam sistem dengan cepat, tepat, aman dan akurat.

2. Sistem yang dirancang dapat menjadi fasilitas baru bagi karyawan dalam mengerjakan soal dan dapat mengetahui hasil nilai kompetensi secara langsung dan cepat.

\section{TUJUAN PENELITIAN}

Adapun tujuan dari penelitian, yaitu:

1. Untuk membantu HRD dalam mendapatkan data valid yang dapat dijadikan sebagai bukti untuk menunjukan apakah karyawan tersebut memenuhi kompetensi minimal atau tidak.

2. Untuk mengetahui pencapaian hasil dari pengukuran uji kompetensi dan untuk mengetahui sistem laporan pengukuran uji kompetensi karyawan yang sedang berjalan pada PT Surya Toto Indonesia.

\section{LITERATURE REVIEW}

Dalam upaya mengembangkan dan menyempurnakan penelitian ini perlu dilakukan studi pustaka (literature review) sebagai salah satu penerapan metode penelitian yang akan dilakukan sebagai bahan perbandingan. Diantaranya yaitu:

1. Penelitian yang dilakukan oleh Siti Untari (2014) STIESIA Surabaya. Berjudul "Pengaruh Kompetensi Dan Lingkungan Kerja Terhadap Kinerja Karyawan Pada CV Buana Mas Jaya Surabaya". Penelitian ini bertujuan untuk mengetahui apakah kompetensi dan lingkungan kerja berpengaruh dan layak terhadap kinerja karyawan. Data yang digunakan dalam penelitian adalah data primer (dari Kuesioner), dan hasil pengujian secara parsial pada tingkat nyata 5\% menunjukkan bahwa variabel kompetensi dan lingkungan kerja masing-masing mempunyai pengaruh yang nyata terhadap kinerja karyawan.

2. Penelitian yang dilakukan oleh Nina Ningsih Panggabean (2013) Berjudul "Pengaruh Kompetensi Terhadap Prestasi Kerja Karyawan Divisi Administrasi Pada PT. Moriss Site Muara Kaman". Penelitian ini bertujuan untuk mengetahui dan menganalisis kompetensi kerja masing-masing karyawan divisi administrasi dapat dilihat dari tingkat kompetensi berdasarkan pendidikan, keterampilan, pengalaman kerja, penguasaan komputerisasi, training atau pelatihan yang pernah dijalani dan motivasi. Metode yang digunakan dalam penelitian ini yaitu metode sensus. Hasil menunjukkan bahwa kompetensi mempengaruhi kinerja sebagai hasil dari nilai koefisien determinasi R2 (persegi) adalah 54,4\%. Sedangkan sisanya adalah 45,6\%, dipengaruhi oleh variabel lain yang terjelaskan pada model. ini menunjukkan bahwa variabel independen secara keseluruhan secara simultan mempengaruhi prestasi kerja karyawan divisi administrasi, dan kontribusi terbesar dari faktor-faktor subkompetensi adalah pengalaman kerja.

3. Penelitian yang dilakukan oleh Ninin Non Ayu Salmah (2012) Universitas PGRI Palembang. Berjudul "Pengaruh Program Pelatihan Dan Pengembangan Karyawan Terhadap Kompetensi Karyawan Pada PT. Muba Electric Power Sekayu”. Penelitian ini bertujuan untuk mengenali pengaruh program pelatihan dan pengembangan 
terhadap kompetensi karyawan berdasarkan keterampilan, pengetahuan dan pengalaman kerja. Adapun pelatihan dilakukan melalui kegiatan pengajaran, pendidikan dan pelatihan yang meliputi materi ilmu pengetahuan, keterampilan dan keahlian. Hasil penelitian menunjukkan program pelatihan dan pengembangan secara signifikan mempengaruhi terhadap kompetensi karyawan secara bersamaan, program pelatihan dan pengembangan secara signifikan mempengaruhi terhadap kompetensi karyawan secara parsial, dan program pelatihan dan pengembangan tidak secara signifikan mempengaruhi terhadap kompetensi karyawan secara parsial.

4. Penelitian yang dilakukan oleh Lian Arcynthia M. (2013) Universitas Hasanuddin Makassar. Berjudul "Analisis Pengaruh Kompetensi Terhadap Kinerja Karyawan Pada PT. Bank Bukopin, Tbk Cabang Makassar". Penelitian ini bertujuan untuk menganalisis pengaruh pengetahuan, keterampilan, perilaku dan pengalaman kerja terhadap kinerja karyawan serta untuk menganalisis variabel yang paling dominan berpengaruh terhadap kinerja karyawan. Berdasarkan hasil analisis yang dilakukan menunjukkan bahwa variabel yang lebih dominan berpengaruh terhadap kinerja karyawan adalah pengalaman kerja.

5. Penelitian yang dilakukan oleh Rifki Aditya, dkk. (2015) Universitas Brawijaya Malang. Berjudul "Pengaruh Pelatihan Terhadap Kompetensi Dan Kinerja Karyawan (Studi Pada Karyawan PT. PLN (Persero) Distribusi Jawa Timur Area Malang)". Penelitian ini bertujuan untuk mengetahui pengaruh pelatihan kerja terhadap kompetensi karyawan, pengaruh pelatihan kerja terhadap kinerja karyawan, dan pengaruh kompetensi karyawan terhadap kinerja karyawan. Jenis penelitian yang dilakukan ini adalah penelitian survey, Dengan adanya program pelatihan diharapkan para karyawan dapat meningkatkan kompetensi karyawan dan kinerja karyawan untuk mencapai sasaran kerja yang telah ditetapkan oleh perusahaan. Pencapaian prestasi kerja yang baik haruslah diikuti oleh peningkatan kompetensi karyawan dan kinerja karyawan.

Adapun kesimpulan dari ke 5 (lima) literature review diatas adalah dengan adanya proses kompetensi pada perusahaan bertujuan untuk mempermudah dan mengetahui kemampuan karyawan, kemudian untuk melakukan penilaian terutama pada penguasaan kompetensi pekerjaan dibidang masing-masing.

\section{LANDASAN TEORI Definisi Sistem}

Menurut Ludwig Von Bertalanfly dalam Yakub (2014:2), "Sistem merupakan seperangkat unsur-unsur yang terkait dalam suatu antar relasi diantara unsur-unsur tersebut dan dengan lingkungannya”.

\section{Definisi Informasi}

Menurut George H.B \& William S.H. (2014:18), "Informasi adalah data diolah sehingga dapat dijadikan dasar untuk mengambil keputusan".

\section{Definisi Website}

Menurut Yosef Murya (2012:3), “Website atau World Wide Web adalah Suatu layanan sajian informasi yang menggunakan konsep hyperlink (tautan) dengan menggunakan media 
untuk memudahkan surfer (sebutan para pemakai komputer yang melakukan browsing atau penelusuran informasi melalui internet)" didalam pencarian informasi.

\section{Definisi Kompetensi}

Menurut Mc.Lelland dalam Moeheriono (2012:6), kompetensi adalah karakteristik dasar personel yang menjadi faktor penentu sukses tidaknya seseorang dalam mengerjakan suatu pekerjaan atau pada suatu situasi tertentu.

\section{Pengukuran Kinerja Karyawan}

Menurut Bangun dalam Skripsi Sherly Vilianti Jeany (2015:14) berpendapat bahwa pengukuran kinerja seseorang dapat diukur melalui:

1. Jumlah Pekerjaan

Dimensi ini menunjukkan jumlah pekerjaan yang dihasilkan individu atau kelompok sebagai persyaratan yang menjadi standar pekerjaan. Setiap pekerjaan memiliki persyaratan yang berbeda sehingga menuntut karyawan harus memenuhi persyaratan tersebut baik pengetahuan, keterampilan, maupun kemampuan yang sesuai.

2. Kualitas Pekerjaan

Setiap karyawan dalam organisasi harus memenuhi persyaratan

tertentu untuk menghasilkan pekerjaan sesuai kualitas yang dituntut oleh suatu pekerjaan tertentu.

3. Ketepatan Waktu

Setiap pekerjaan memiliki karakteristik yang berbeda, untuk jenis pekerjaan tertentu harus diselesaikan tepat waktu, karena memiliki ketergantungan atas pekerjaan lain. Jadi, apabila pekerjaan tertentu tidak selesai tepat waktu akan menghambat pekerjaan pada bagian lain, sehingga mempengaruhi jumlah dan kualitas hasil pekerjaan.

4. Kehadiran

Suatu jenis pekerjaan tertentu menuntut kehadiran karyawan dalam

mengerjakannya sesuai waktu yang ditentukan.

5. Kemampuan Kerja Sama

Tidak semua pekerjaan dapat diselesaikan oleh satu orang karyawan saja. Untuk pekerjaan tertentu mungkin harus diselesaikan oleh dua orang atau lebih, sehingga kerja sama antar karyawan sangat dibutuhkan. Kinerja karyawan dapat dinilai dari kemampuan kerja sama antar rekan kerja.

Adapun Pada PT Surya Toto Indonesia memiliki rumusan atau formula yang digunakan sebagai pengukuran kompetensi karyawan, dengan tujuan untuk mempermudah dalam penilaian uji kompetensi karyawan sebagai berikut, yaitu:

1. Jika karyawan dapat menjawab soal $\leq 2$ item (maka belum kompeten) dari 5 soal yang diberikan.

2. Jika karyawan dapat menjawab soal $\leq 3$ item (maka kurang kompeten) dari 5 soal yang diberikan.

3. Jika karyawan dapat menjawab soal $\leq 4$ item (maka mendekati kompeten) dari 5 soal yang diberikan.

4. Jika karyawan dapat menjawab 5 item (maka kompeten) dari 5 soal yang diberikan.

\section{Penilaian Kinerja}

Menurut Nawawi dalam Skripsi Bagas Adi Prakoso (2015:10) pengertian penilaian kinerja adalah proses pengamatan (observasi) terhadap pelaksanaan pekerjaan oleh seorang 
pekerja. Dari hasil observasi (pengamatan) itu dilakukan pengukuran yang dinyatakan dalam bentuk penetapan keputusan mengenai keberhasilan atau kegagalannya dalam bekerja.

\section{PEMBAHASAN}

PT Surya Toto Indonesia merupakan salah satu produsen produk saniter terbesar di Asia Tenggara, yang berkantor pusat di Tomang Raya, Jakarta Barat. Sejarah perusahaan ini dimulai dari kerjasama antara CV Surya dengan TOTO Ltd di Jepang pada tahun 1968 yang berbisnis dalam pertukaran bahan materials. CV Surya menjalin kerjasama dengan TOTO Ltd yang merupakan salah satu perusahaan besar dan terkemuka di dunia.

Menyadari bahwa bidang usaha ini memiliki prospek yang cerah di Indonesia, maka pada tahun 1977 PT. Surya Toto Indonesia. Tbk berdiri sebagai usaha kerjasama antara CV. Surya dengan Kashima Trading Company dan TOTO Limited. Indonesia mendapat keuntungan dari sumber daya yang digunakan dalam jumlah besar, yang meliputi pekerja terampil, bahan baku yang berlimpah-limpah dan bahan bakar.

Pada Tahun 1978 pabrik saniter pertama berdiri di Serpong. Tangerang dengan jumlah karyawan 65 orang. Pada tahun 1994 PT. Surya Toto Indonesia berhasil memperoleh label dari JIS (Japan International Standard) dan juga berhasil menambah tipe produk yang dihasilkan. Kemudian pada tahun 1999 PT. Surya Toto Indonesia memperoleh sertifikasi ISO 9002.

Pada saat ini, perusahaan telah mengekspor produknya ke 20 negara melalui agen-agen internasional yang dimiliki di beberapa benua. Jaringan penjualan dalam negeri yang dimiliki perusahaan juga sangat luas, meliputi 14 agen dan sub agen yang didukung oleh lebih dari 800 dealer lokal yang berada di lebih dari 20 kota kecil diseluruh Nusantara. Kini perusahaan memiliki dua pabrik utama saniter di Desa Bojong, Cikupa dan Pabrik fitting di Jl. M. H. Thamrin Km 7, Serpong, dengan total karyawan lebih dari 2300 orang.

Tata laksana sistem yang berjalan pada PT Surya Toto Indonesia Tbk, maka tahapan prosedur sistem yang berjalan pada sistem uji kompetensi karyawan,dengan urutan sebagai berikut: 1) HRD membuat rencana terlebih dahulu untuk melakukan uji kompetensi dan jadwal yang berisikan daftar nama karyawan, untuk melaksanakan uji kompetensi, dan diberikan kepada supervisor. 2) Supervisor akan memproses jadwal uji kompetensi, dengan mendata siapa saja karyawan yang terdata pada jadwal uji kompetensi tersebut. 3) Karyawan akan melaksanakan uji kompetensi berupa tes tertulis yang akan dilaksanakan dalam jangka waktu selama 1 minggu dan selama 1 jam sehari, sesuai jadwal yang telah diberikan oleh supervisor. 3) HRD akan memeriksa hasil tes tertulis dan memberikan nilai yang telah dilakukan oleh karyawan dan menginput hasil nilai kompetensi. 4) Laporan hasil kompetensi karyawan yang berupa laporan hardcopy akan didistribusikan kepada supervisor pada bagian masing-masing. Dimana laporan hasil kompetensi tersebut digunakan untuk memberikan informasi hasil nilai kompetensi kepada karyawan. Dibawah ini merupakan gambaran sistem pengukuran uji kompetensi karyawan pada PT Surya Toto Indonesia yang berjalan digambarkan melalui bentuk gambar ilustrasi sebagai berikut : 


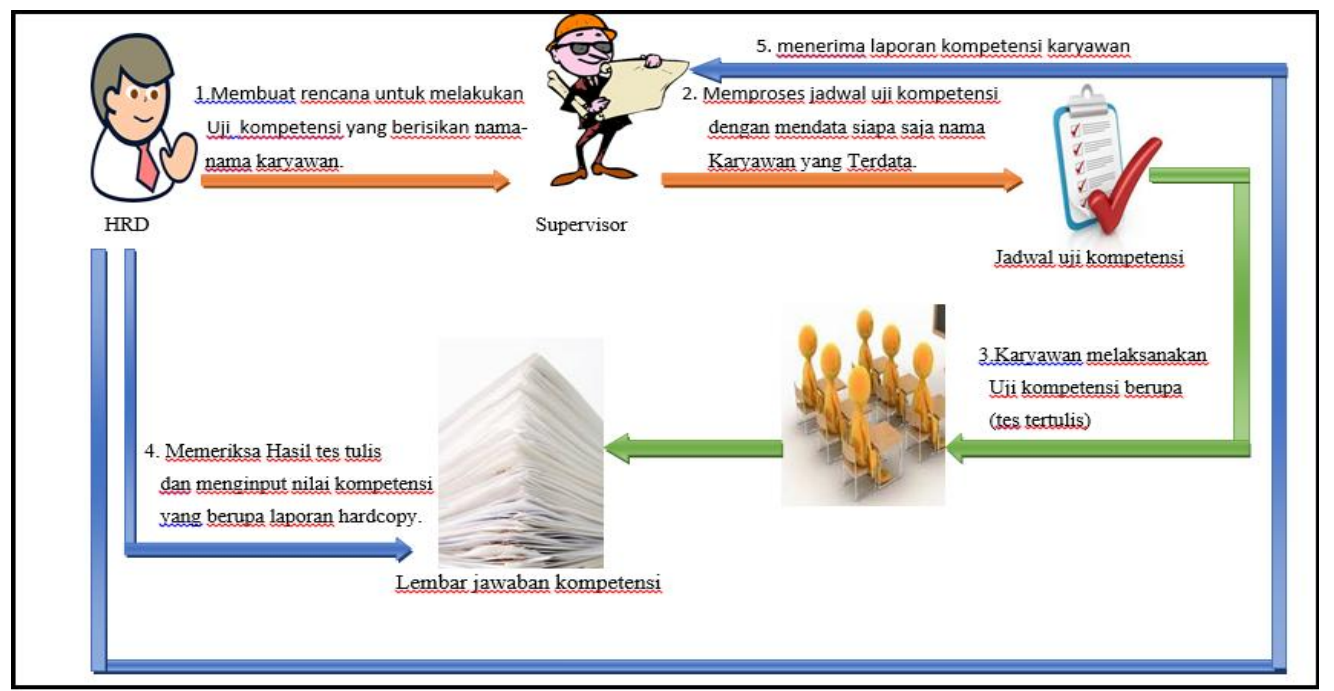

Gambar 1. Sistem Pengukuran Uji Kompetensi Karyawan

Keterangan gambar 1 tentang alur sistem pengukuran uji kompetensi karyawan, yaitu: 1) membuat rencana untuk melakukan uji kompetensi yang berisikan nama-nama karyawan. 2) memproses jadwal uji kompetensi dengan mendata siapa saja nama karyawan yang terdata. 3) karyawan melaksanakan uji kompetensi berupa (tes Tertulis). 4) memeriksa hasil tes tulis dan menginput nilai kompetensi yang berupa laporan hardcopy. 5) menerima laporan kompetensi karyawan.

\section{MODEL SISTEM}

Model sistem pengukuran uji kompetensi yang terdapat pada PT Surya Toto Indonesia Tbk Kabupaten Tangerang :

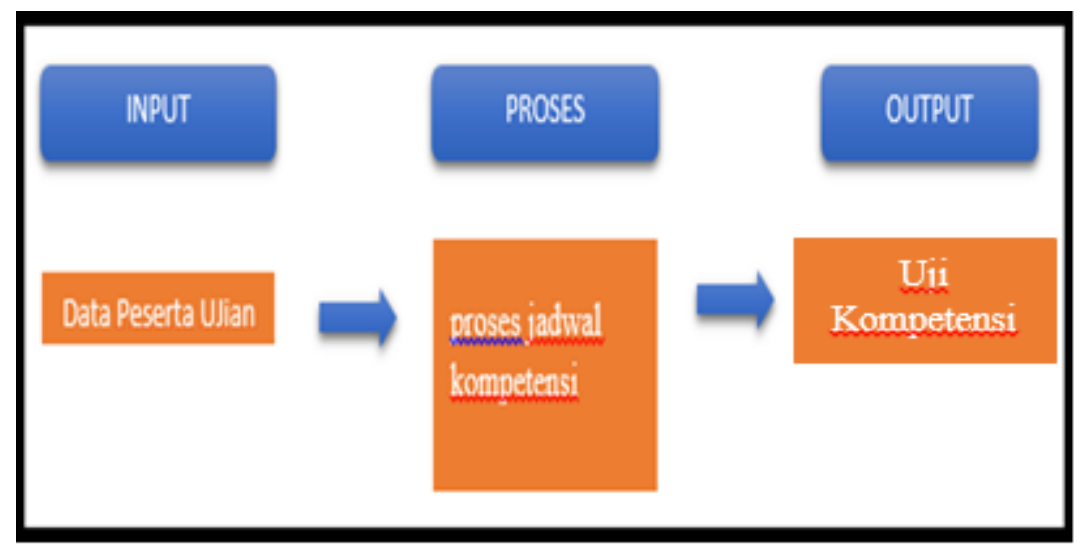

Gambar 2. Model Sistem Pengukuran Uji Kompetensi PT Surya Toto Indonesia Tbk

Keterangan :

1) Inputan data peserta ujian yang berupa dokumen akan diproses, dimana proses ini digunakan untuk jadwal uji kompetensi.

2) Data peserta ujian akan dilakukan proses lanjutan yaitu proses jadwal kompetensi.

3) Masing-masing peserta ujian akan melaksanakan uji kompetensi . 
Kegunaan dari model sistem tersebut adalah untuk menggambarkan model alur sistem yang terdapat dalam PT Surya Toto Indonesia Tbk, selain itu model sistem juga digunakan sebagai skema alur dari perancangan sistem yang diusulkan oleh peneliti.

\section{IMPLEMENTASI}

Tampilan login merupakan tampilan utama dari sistem, setiap user yang ingin masuk ke dalam sistem maka harus melakukan login terlebih dahulu dengan memasukan username dan password yang benar.

Berikut dibawah ini merupakan tampilan login Sistem Informasi Pengukuran uji kompetensi karyawan pada PT Surya Toto Indonesia:

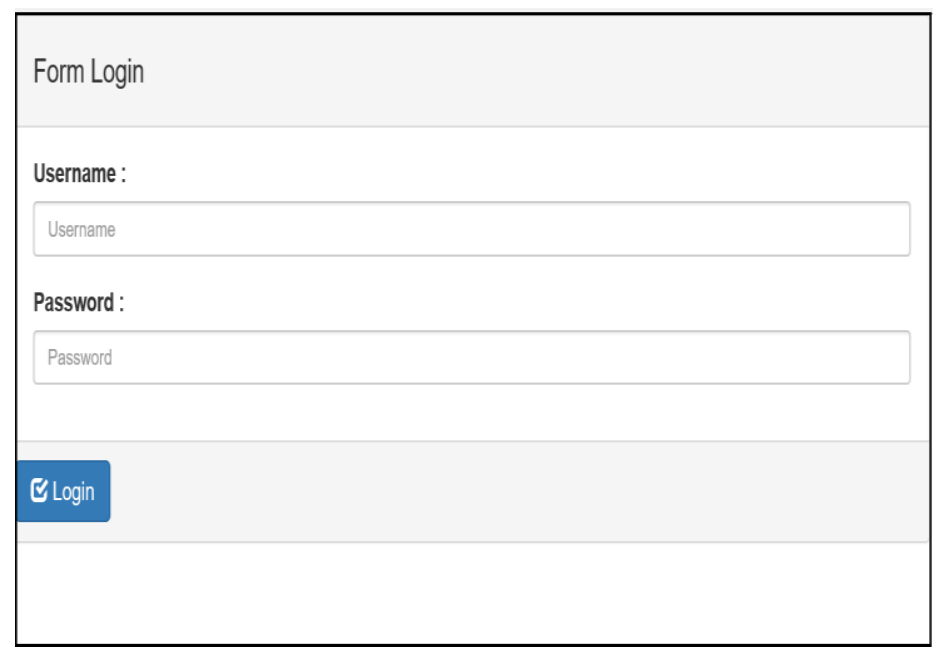

Gambar 3. Tampilan Halaman Login

Gambar diatas merupakan halaman utama sistem yang berisikan tampilan login user dengan menggunakan username dan password yang telah ditentukan.

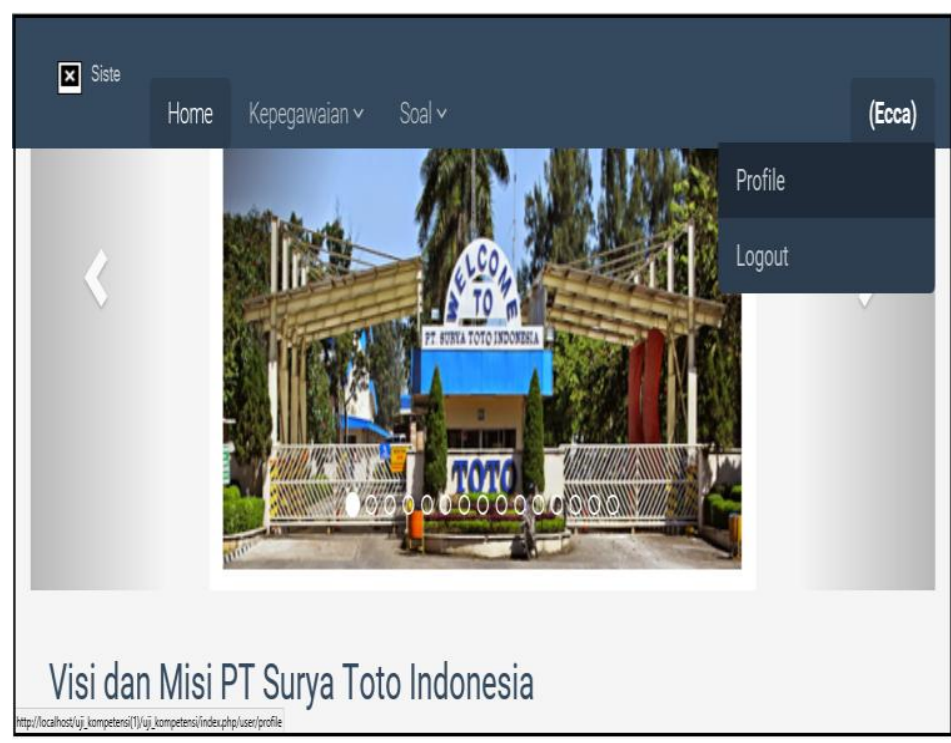

Gambar 4 Tampilan Halaman Home

Gambar diatas merupakan halaman utama sistem setelah admin berhasil login dengan menggunakan username dan password yang telah ditentukan. 


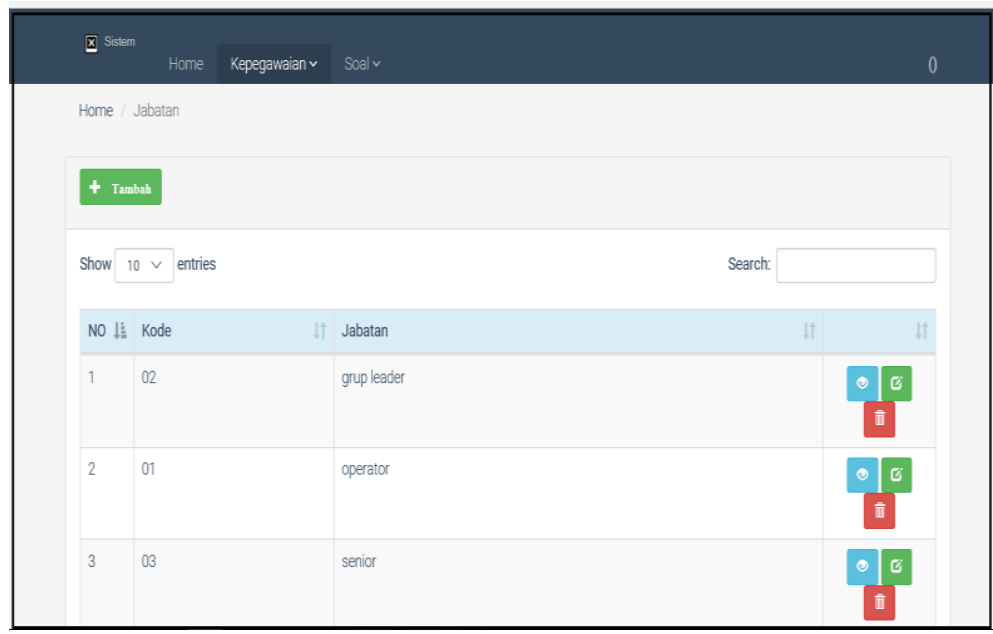

Gambar 5 Tampilan Halaman Jabatan

Halaman jabatan adalah halaman yang berisikan daftar data jabatan.

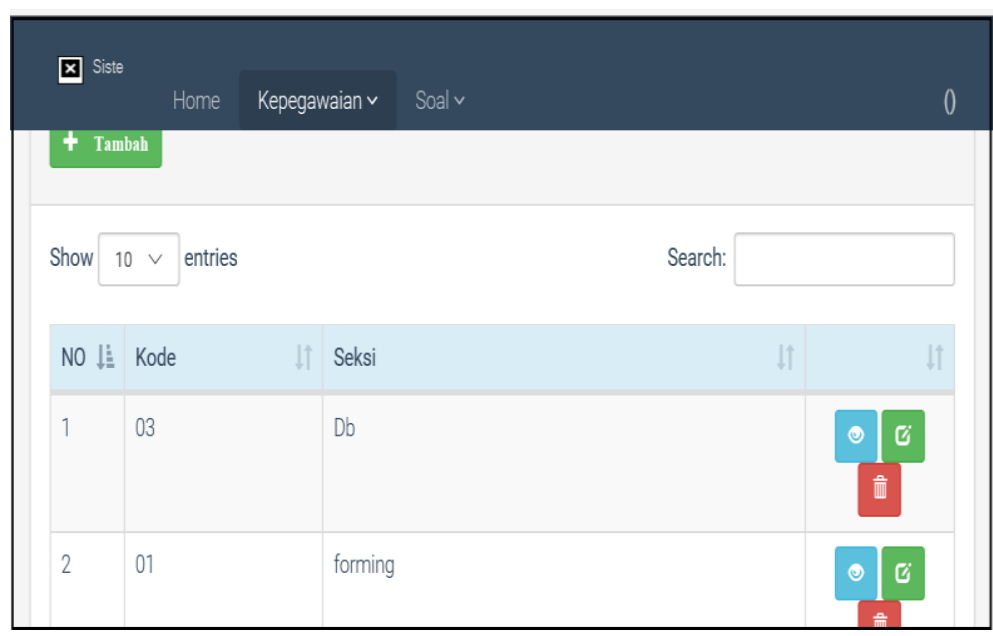

Gambar 6. Tampilan Halaman daftar seksi

Halaman seksi adalah halaman yang berisikan daftar data seksi.

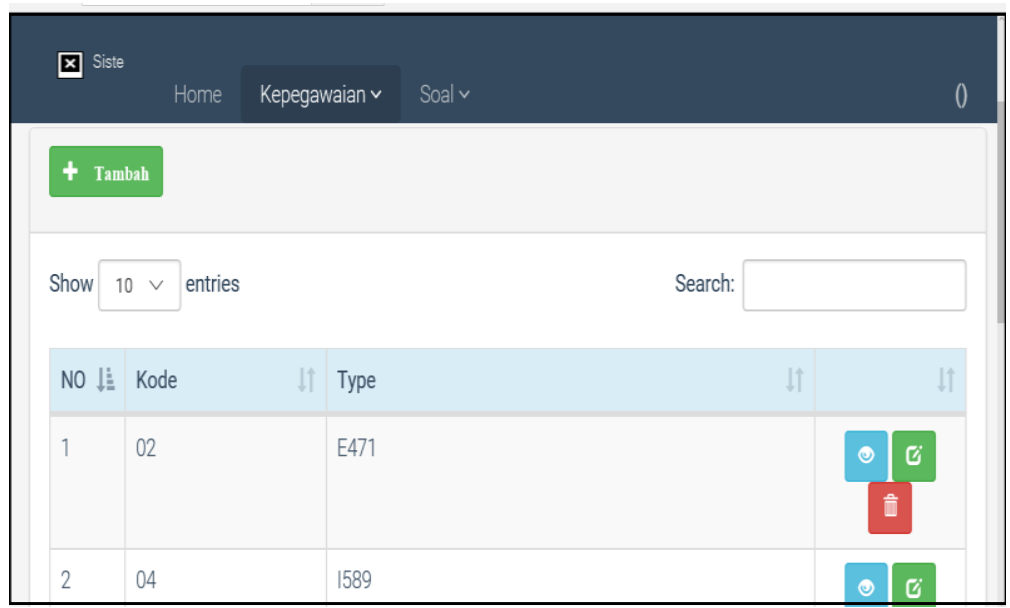

Gambar 7. Tampilan Halaman daftar type

Halaman type adalah halaman yang berisikan daftar data type. 


\section{KESIMPULAN}

Berdasarkan hasil penelitian yang telah dilakukan, maka dapat ditarik kesimpulan sebagai berikut :

1. Sistem laporan hasil pengukuran uji kompetensi yang berjalan saat ini sudah menggunakan komputer namun baru sebatas Microsoft Office, mulai dari proses penginputan data nilai dan proses pembuatan rekap penilaian kompetensi. Sehingga dalam pengolahan datanya banyak memakan waktu, yang mengakibatkan penyampaian laporan menjadi terlambat.

2. Uji kompetensi yang berjalan saat ini belum menggunakan komputerisasi, sehingga menyebabkan menumpuknya lembar jawaban soal uji kompetensi. Agar sistem yang berjalan bisa berjalan lebih efektif dan efisien maka dibutuhkan sistem informasi pengukuran uji kompetensi berbasis website dengan bahasa pemrograman PHP dan MySQL sebagai penyimpanan databasenya.

\section{DAFTAR PUSTAKA}

[1] Bagas Adi Prakoso. 2015. "Analisis Pengaruh Kompensasi Dan Kepemimpinan Terhadap Kinerja Karyawan”. Semarang: Universitas Diponegoro.

[2] H.B, George, William S.H.2014.”Sistem Informasi Manajemen”. Yogyakarta:Graha Ilmu.

[3] Lian Arcynthia M. 2013. "Analisis Pengaruh Kompetensi Terhadap Kinerja Karyawan Pada PT. Bank Bukopin, Tbk Cabang Makassar”. Universitas Hasanuddin Makassar.

[4] Moeheriono, Misbachul Munir. 2015. " Pengaruh Pendidikan Pelatihan, Mutasi Jabatan Dan Kemampuan Kerja Terhadap Kinerja Karyawan Pada Pt.Bank Jatim,Tbk. Cabang Jember". Universitas Jember.

[5] Murya,Yosef. 2012."PHP Menyele- saikan Website 30 Juta”. Yogya- karta: Jasakom.

[6] Nina Ningsih.2013."Pengaruh Kompetensi Terhadap Prestasi Kerja Karyawan Divisi Administrasi Pada PT. Moriss Site Muara Kaman”. eJournal Administrasi Bisnis, 2013, $12: 104-113$

[7] Ninin Non Ayu Salmah. 2012. "Pengaruh Program Pelatihan Dan Pengembangan Karyawan Terhadap Kompetensi Karyawan Pada PT. Muba Electric Power Sekayu”. Universitas PGRI Palembang.

[8] Rifki Aditya. 2015. "Pengaruh Pelatihan Terhadap Kompetensi Dan Kinerja Karyawan (Studi Pada Karyawan PT. PLN (Persero) Distribusi Jawa Timur Area Malang)". Jurnal Administrasi Bisnis (JAB) Vol. 27 No. 2 Oktober 2015. Universitas Brawijaya Malang.

[9] Sherly Vilianti Jeany. 2015. "Pengaruh Kepuasan Kerja, Komitmen Organisasi, Dan Budaya Organisasi Terhadap Kinerja Karyawan (Studi pada PT Telekomunikasi Indonesia Unit Bagian Witel Semarang)". Semarang: Universitas Diponegoro.

[10] Siti Untari.2014. "Pengaruh Kompetensi Dan Lingkungan Kerja Terhadap Kinerja Karyawan Pada CV Buana Mas Jaya Surabaya”. Jurnal Ilmu \& Riset Manajemen Vol. 3 No. 10 .2014.STIESIA Surab 